\title{
Test of Monetary Approach to Balance of Payments in West Africa Monetary Zone
}

\author{
Foluso Ololade Oluwole \\ Department of Banking and Finance \\ Adekunle Ajasin University, Akungba Akoko; Ondo State, Nigeria \\ E-mail: foluso.oluwole@aaua.edu.ng \\ John Adebayo Oloyede \\ Department of Banking and Finance \\ Ekiti State University; Ado Ekiti, Ekiti State, Nigeria \\ E-mail: ololadefo8I@gmail.com
}

\begin{abstract}
This research tested the monetary approach to Balance of Payment in developing countries of West Africa in order to affirm whether the specified relationship in the approach depicts correctly the actual behaviour of the economies. Time series and crosssectional data that ranges from I970 - 2016 were used. The empirical results of the fixed effect model established a significant positive relationship between net domestic credit, interest rate and exports; an insignificant positive relationship between capital movements, imports, income and the dependent variable. Exchange rate, however, had a significant negative relationship with the net foreign assets, while inflation had an insignificant but negative relationship with net foreign assets. The pairwise causality tests indicated a unidirectional relationship between exchange rate, net domestic credit and net foreign assets while the other variables move independently and cannot granger cause net foreign assets. Hence, the study concludes that the Polak model is valid in the West Africa Monetary Zone despite the fact that they are no more operating a fixed exchange rate system. The study suggests that the attention of the monetary authorities and the governments should not only be on decreasing the money supply in the economy, since an increase in net domestic credits has a positive impact on the net foreign assets provided it is channeled towards domestic production.
\end{abstract}

Keywords: Balance of Payment, Foreign Exchange, Monetary Approach, Current Account Deficit, Money Supply.

JEL Codes: E42, F3I, EI2, F32, E5I.

\section{Introduction}

It has been observed over time among developing countries that there is a prevalence of persistence current account deficit which is a major cause of concern because, maintaining a healthy and stable balance of payment and promoting trade drives rapid economic growth. Therefore, the management and sustenance of balance of payment (BOP) equilibrium is of great importance for developing countries to pursue (Boateng and Ayentimi, 2013; Umer, 2010; Ogiogio, I996 and Obionna,I998). An examination on the problem of BOP imbalances by Martin (2014) revealed that out of the 66 poorer developing counties (low income and lower middle-income countries), 52 had a current account deficit. The current account deficits in these states are common than in other groups of nations due to the great effect of external factors that cannot be influenced and it is also a sign of the endeavours of countries with less capital to accelerate economic development by means of net capital imports.

Also, despite the relatively extensive body of theoretical and empirical literature on this subject matter, there are only a few comprehensive studies that empirically analyse the effect of macroeconomic variables of the polak model on the BOP position of West African countries. For example, Stephen and Njuyuna (2000) applied the old Polak model to Kenya, pointing out that the behavioural equation of the Polak model ignores the other determinants of money balances like interest rate, inflation and wealth. It assumed that changes in domestic credit have no effect on the determinants of money demand. The study is also in conformity with the work of (Nwakama, 2013; Duasa, 2005; Ajayi, 20I4; Tijani, 2004; Johnson, I976; Aghevli and Khan, 1977; Connolly and Taylor, 1976; Humphrey, 1976, 1977; Musa 1976). The monetary approach also assumed a fixed exchange rate regime. The definitional equation also treated export as being determined exogenously, which is only realistic if the exchange rate is fixed. Once an exchange rate is flexible, it becomes endogenous (Khan, 2008). Adamu and Itsede (20I0), however, in their study of monetary approach to BOP in West Africa monetary zone, filled the above gap by including other determinants of money demand like inflation and interest rate but ignored the effect of exchange rate volatility on BOP as a control variable that the monetary authority should also focus on, in addition to the net domestic credit (Polak I997). 
This sparked off the emergence of an empirical research and better evidence to validate the monetary approach in resolving the BOP crisis in the selected West African countries through the modified Polak model. In view of this, the study tends to investigate the relationship between BOP, proxy as net foreign assets and some macroeconomic variables in the selected countries. The investigation is an attempt to examine the extent to which the monetary theory approach explains the observed behaviour of BOP problem of West African countries that operates the floating exchange rates.

\section{Literature Review}

The application of Polak model to Namibia was also carried out by Fleermuys (2005). The monetary approach to Namibia's BOP was tested on the basis of quarterly data covering the period 1993 to 2003, in which Net foreign assets is a function of economic growth, inflation, interest rate and net domestic credit using the Engel-Granger approach to long run estimation to test whether BOP is a monetary phenomenon on the long run. It was found out that the BOP in Namibia is not a purely monetary phenomenon because only inflation and domestic credit have a significant relationship with net foreign assets. The study thus concluded that the monetary authorities should pay special attention to domestic credit and to also achieve sufficient economic growth through money demand to correct the balance of payments deficit. This conforms with the works of Menzie and Eswar,2002; Dausa, 2005; Makin, 2005; khan, 2008; Boateng and Ayentimi (2013); Iyoboyi and Mufutau (2014); Shuaib, Augustine and Frank,2015

The study conducted by Braima and Korsu (2013) tested whether the balance of payments of Sierra Leone is a monetary phenomenon, using aggregate annual data for Sierra Leone from 1970 to 2010. A reserve flow model was estimated. Due to the inherent tendency of non-stationary of macroeconomic variables and their attendant spurious effects on time series regression estimates, tests for stationary of the variables were carried out. Given the existence of non-stationary in the variables, which were however found to be stationary under linear combination (were co-integrated); an error correction model was estimated. The result showed that the balance of payments of Sierra Leone is a monetary phenomenon, driven by changes in domestic credit, the price level, exchange rate and interest rate. Domestic credit, interest rate and the price level have negative effects on the balance of payments of Sierra Leone while the exchange rate has a positive effect. However, the importance of the price level is felt with a delayed impact. According to them, the policy implication is that monetary policy operations that are consistent with low and stable inflation, domestic credit restraint and exchange rate depreciation are important for improvement of the BOP of Sierra Leone, with low and stable inflation being more useful for medium term objective. Supporting these views are the works of Aghevli and Khan, I977; Dhliwayo, 1996; Tijani, 2004; Imoisi,20I2; Umoru and Odjegba (2013); Ajayi, 2014.

For a cross country study in Africa, Taiwo (I992), using Bayesian posterior odds ratio, sampled ten (I0) African countries from 1960-1990, to assess their BOP crisis. He concluded that about 50 percent of the countries sampled were experiencing a fundamental disequilibrium in their current and capital accounts. He noted that the economic crisis facing most African countries is multi-dimensional, and must not in any way be compared with the BOP predicament that they are facing. The view of Nyong and Obafemi (1995) and that of Arewa and Nwakama(2013) are that government needs to look beyond the issue of money supply in solving the BOP issues.

Most of the studies reviewed above view balance of payment problem as a monetary phenomenon and not a real phenomenon while some have mixed results. It is also noted that a lot of work has been done on the developed countries and developing countries. Despite the application of the monetary approach, even by the IMF to various countries, they are still experiencing deficits in their balance of payment position. Using various models by different authors, and the conventional theories, there is need to carry out this study on the African countries, most especially the West African countries whose external sector has undergone profound changes over the years viewed from the trend of their BOP position. Most of these countries run current account deficits alongside low levels of investment and economic growth, which may not be beneficial to them on the long run. The study, however intends to investigate the validity of the assumption that BOP deficits or surplus in the West African countries, is a monetary phenomenon, using the modified Polak model (Polak, I997).

\section{Methods}

The research design for this study is the correlation research design as the model focuses on the relationship between credit expansion and change in foreign assets and its effect on the BOP. The key variable according to the model which the authorities could control is the domestic credit creation.

\section{I Model Specification}

To test the efficacy of the monetary approach on balance of payment proxy as net foreign assets, the equation in a functional form is given as:

$N F A=f(N D C, C M, E X P, I N C, M C I P, I N F, I N T)$. 
The modified version of the Polak model as in Yotzov (200I), Adamu and Itsede (2010), Wioletta (2013) with the inclusion of exchange rate as an additional policy variable to the net domestic credit was tested in the usual equation as:

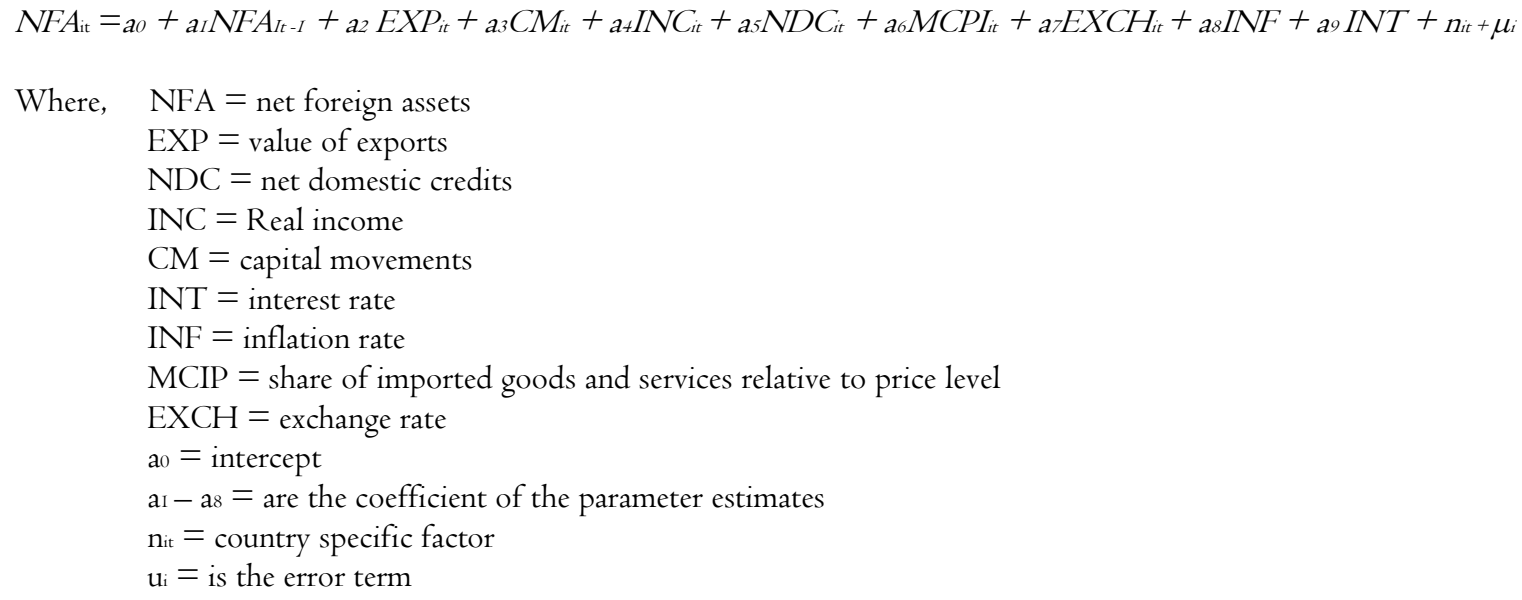

\subsection{A Priori Expectation}

It is expected that the coefficients of domestic credit, price index, interest rate, and inflation will be negative while exchange rate, income, exports and imports will be positive. Theoretically, it is expected that low exchange rate will encourage importation and this will worsen the balance of payment position. Also, the growth of GDP will increase when exports exceed import which basically improves BOP. When there is inflation in an economy, people tend to rely on imported goods whose price does not change, therefore bringing about unfavourably BOP.

Mathematically: $a 1, a_{3} a 5, a_{6}>0$ while $a 2, a 4, a$ and $a s<03.4$

\subsection{Estimation Techniques}

The choice of estimation depends on the specification of model, the nature of the available data and the purpose of the model. The fixed effects model takes into account the panel structure of the data and assumes that the individual heterogeneity among the countries is captured by the intercept. The intercept of the model does not vary over time i.e. it is time invariant. Therefore the model was estimated using the panel fixed effect model. Different diagnostic tests were also conducted to check the validity of the model. The panel unit root to test the level of stationary, the panel co-Integration to guide against spurious regression and the Hausman tests to determine whether the fixed or the random effect would be suitable for the model under study.

\subsection{Sources of Data}

Annual time series data covering the period of 1970 - 2018 were sourced to test the Polak model of the monetary approach to BOP in the West African Monetary Zones (Ghana, Gambia, Guinea, Liberia, Nigeria and Sierra Leone). These data were sourced from secondary sources which include: the IMF's International Financial Statistics, West Africa Monetary Institute (WAMI) database, World Development Indicators, Organisation for Economic Community Development (OECD) data base. However, the data for guinea was not all available and so; the analysis was based on the other five countries, excluding Guinea

\subsection{Statistical Definition of Variables}

For the purpose of the study under review, the following definitions are adopted:

- Net Domestic Credit (NDC): is defined as the sum of the net claims on the central bank and claims on other sectors of the economy measured in local currency unit.

- Income (Y): is identified as the gross domestic product (GDP) rate annual percentage, that is the annual percentage growth rate of GDP at market prices based on constant local currency.

- Net Foreign Assets (NFA): represents the nets foreign assets held by monetary authorities and deposit money banks, less their foreign liabilities measured in current local currency.

- Exports $(\mathrm{X})$ : The export value index was used; that is, the current value of exports converted to US dollars and expressed as a $\%$ of the coverage for the base period (2000).

- Capital Movements (CM) covers the net capital inflows of the non-banking sector.

- Import (MCPI): This is measured as the annual growth rate of imports of goods and services based on constant local currency, aggregate based on constant 2010 US dollars. 
- Exchange rate $(\mathrm{EXCH})$ : The official exchange rate was used, calculated as an annual average based on monthly averages (local currency units relative to dollars).

- Interest rate (INT): this represents the deposit interest rate measured by the rate paid by commercial banks for demand, time and savings deposit.

- Inflation rate (INF): inflation was measured by the annual growth rate of the GDP implicit deflator, that is, the ratio of GDP in constant local currency.

\section{Results}

4.I Descriptive Statistics

Table I. Descriptive Statistics

\begin{tabular}{|c|c|c|c|c|c|c|c|c|c|}
\hline & NFA & $\mathrm{NDC}$ & MCIP & INT & INF & INC & EXPT & $\mathrm{EXCH}$ & $\mathrm{CM}$ \\
\hline Mean & $3.83 \mathrm{E}+\mathrm{II}$ & $5.93 \mathrm{E}+\mathrm{II}$ & I5.95938 & I3.0139I & 19.35887 & 3.336903 & I.86E+II & $268.788 \mathrm{I}$ & $\mathrm{I.73E}+\mathrm{II}$ \\
\hline Median & 21389119 & I.05E+09 & II.76600 & $\mathrm{I} 2.47208$ & II.593I6 & 4.168448 & 13316120 & 2.084538 & 46642816 \\
\hline Maximum & $8.72 \mathrm{E}+\mathrm{I} 2$ & $\mathrm{I} .96 \mathrm{E}+\mathrm{I} 3$ & 96.26080 & 35.75917 & I78.7003 & I06.2798 & $5.70 \mathrm{E}+\mathrm{I} 2$ & 4524.158 & $6.55 \mathrm{E}+\mathrm{I} 2$ \\
\hline Minimum & $-4.22 \mathrm{E}+\mathrm{II}$ & $-3.14 \mathrm{E}+08$ & -54.34199 & 1.833333 & -35.83668 & $\begin{array}{l}- \\
51.03086\end{array}$ & -II5I38.3 & 0.000102 & $-9.24 \mathrm{E}+08$ \\
\hline Std. Dev. & $\mathrm{I} .50 \mathrm{E}+\mathrm{I} 2$ & $2.46 \mathrm{E}+\mathrm{I} 2$ & 27.13448 & 6.112069 & $24.2 \mathrm{I} 256$ & II.27003 & $6.01 E+I I$ & 841.9288 & $8.27 \mathrm{E}+\mathrm{II}$ \\
\hline Skewness & 4.274297 & 5.802849 & 0.128018 & $0.98840 \mathrm{I}$ & 3.012703 & $2.54598 \mathrm{I}$ & 6.428859 & 3.634825 & 6.006569 \\
\hline Kurtosis & 20.66077 & $38.08 \mathrm{I} 4 \mathrm{I}$ & 2.654650 & $4.457 \mathrm{IOI}$ & 15.02110 & 36.48484 & 53.48722 & I5.59943 & 40.05378 \\
\hline Jarque-Bera & 3593.160 & $\mathrm{I} 2743.7 \mathrm{I}$ & I.724998 & $56.2883 \mathrm{I}$ & I687.58I & I0706.85 & 25333.28 & I974.872 & I4I6I.45 \\
\hline Probability & 0.000000 & 0.000000 & 0.422106 & 0.000000 & 0.000000 & 0.000000 & 0.000000 & 0.000000 & 0.000000 \\
\hline Sum & $8.58 \mathrm{E}+\mathrm{I} 3$ & $\mathrm{I} .33 \mathrm{E}+\mathrm{I} 4$ & $3574.90 \mathrm{I}$ & 2915.115 & 4336.386 & 747.4663 & $4.16 \mathrm{E}+\mathrm{I3}$ & 60208.53 & $3.88 \mathrm{E}+\mathrm{I} 3$ \\
\hline Sum Sq. Dev. & $5.04 \mathrm{E}+26$ & $1.35 \mathrm{E}+27$ & I64I90.4 & 8330.696 & I30733.3 & 28324.05 & $8.06 \mathrm{E}+25$ & $\begin{array}{l}1.58 \mathrm{E}+0 \\
8 \\
\end{array}$ & $1.52 \mathrm{E}+26$ \\
\hline Observations & 224 & 224 & 224 & 224 & 224 & 224 & 224 & 224 & 224 \\
\hline
\end{tabular}

Source: Researcher's Computation 2019

From table I, the mean results of all the variables showed a significant value, the median and maximum equally revealed a significant value while the minimum descriptive statistics of Net Foreign Asset (NFA), Net Domestic Credit (NDC), MCIP, Inflation (INF), Real Income (INC), Export (EXPT), and Capital Movements (CM) revealed negative minimum contributions meanwhile Interest Rate (INT) and Exchange Rate (EXCH) reported positive contributions.

From Skewness statistic, it indicated that all the variables were positively skewed, while Kurtosis statistic displayed that all variables were leptokurtic (fat tailed) in nature. The Jarque-Bera statistic value showed significant contributions. However, the descriptive analysis revealed that the variables were normally distributed with 224 observations.

\subsection{Panel Unit Root Result}

The unit root test was carried out using the Im, Perasan and Shin Methos. The results are presented in table 2 to table 4

Table 2. Im, Pesaran \& Shin Unit Root Test at Level

\begin{tabular}{llll}
\hline Variable & Statistic & Prob. & \\
\hline NFA & 3.76907 & 0.9999 & Non-Stationary \\
\hline NDC & 3.63730 & 0.9999 & Non-Stationary \\
\hline MCIP & -2.39857 & 0.0082 & Stationary \\
\hline INT & -0.05629 & 0.4776 & Non-Stationary \\
\hline INF & -3.64146 & 0.0001 & Stationary \\
\hline INC & -6.37563 & 0.0000 & Stationary \\
\hline EXPT & -1.04578 & 0.1478 & Non-Stationary \\
\hline EXCH & I.84I9I & 0.9673 & Non-Stationary \\
\hline CM & -4.10924 & 0.0000 & Stationary \\
\hline & Source: Researcher's computation (2019) &
\end{tabular}


Table 3. Im, Pesaran \& Shin Unit Root Test at First Difference

\begin{tabular}{llll}
\hline Variable & Statistic & Prob & \\
\hline NFA & -8.35293 & 0.0000 & Non-Stationary \\
\hline NDC & -10.3402 & 0.0000 & Non-Stationary \\
\hline INT & -10.0086 & 0.0000 & Non-Stationary \\
\hline EXPT & -5.80371 & 0.0000 & Non-Stationary \\
\hline EXCH & -7.00957 & 0.0000 & Non-Stationary \\
\hline \multicolumn{5}{r}{} & Source: Researcher's computation (2019).
\end{tabular}

Table 4. Order of Integration

\begin{tabular}{ll}
\hline Variable & Order of Integration \\
\hline NFA & $\mathrm{I}(\mathrm{I})$ \\
\hline NDC & $\mathrm{I}(\mathrm{I})$ \\
\hline MCIP & $\mathrm{I}(0)$ \\
\hline INT & $\mathrm{I}(\mathrm{I})$ \\
\hline INF & $\mathrm{I}(0)$ \\
\hline INC & $\mathrm{I}(0)$ \\
\hline EXPT & $\mathrm{I}(\mathrm{I})$ \\
\hline EXCH & $\mathrm{I}(\mathrm{I})$ \\
\hline CM & $\mathrm{I}(0)$ \\
\hline \multicolumn{2}{c}{ Source: Researchers' computation (2019) }
\end{tabular}

Table 2, 3 and 4 revealed Im, Pesaran and Shin (IPS) Panel Unit Root test, which was employed to test for the stationarity of the variables. The results were presented in level and first difference at 5\% significance level. The result showed that MCIP, INF, INC and CM were stationary at level while other variables such as NFA, NDC, INT, EXPT and (EXCH) became stationary only after first differencing at 5\% alpha level of significance. This implies that the variables retained shock for short period, after which they let go and this necessitated the use of Panel Auto-regressive Distributed Lag (P-ARDL).

\subsection{Lag Selection Criteria}

The Likelihood Ratio test (LR), Final Prediction Error criteria (FPE), Akaike Information Criterion (AIC), Schwarz Information Criterion (SC) and Hannan-Quinn Information Criteria (HQIC) were applied for the selection of lag length. The Criteria suggestion is then presented below for the estimation of the Panel ARDL.

Table 5. Lag Length Selection Criteria

\begin{tabular}{lllllll}
\hline Lag & LogL & LR & FPE & AIC & SC & HQ \\
\hline 0 & -28868.59 & NA & $4.7 \mathrm{e}+\mathrm{IIO}$ & 280.3649 & 280.5103 & 280.4237 \\
\hline $\mathrm{I}$ & $-27 \mathrm{I} 0 \mathrm{I} .08$ & 3363.405 & $3.6 \mathrm{e}+\mathrm{I03}$ & $263.99 \mathrm{II}$ & $265.4450^{* *}$ & $264.579 \mathrm{I}$ \\
\hline 2 & -26953.74 & $267.503 \mathrm{I}$ & $1.9 \mathrm{e}+\mathrm{I03}$ & 263.3470 & 266.1095 & 264.4642 \\
\hline 3 & -26698.42 & $44 \mathrm{I} .2406^{* *}$ & $3.5 \mathrm{e}+\mathrm{I02}$ & $26 \mathrm{I} .6545^{\text {** }}$ & 265.7255 & $263.3010^{* *}$ \\
\hline
\end{tabular}

Source: Researchers' computation (2019)

The results indicated that Likelihood Ratio (LR), Final Prediction Error (FPE), Akaike Information Criterion (AIC), Schwarz Criterion (SC) and Hannan-Quinn Criterion (HQ) predicted 3, 3, 3, I, and 3, lag respectively. The study then selected the lag length of Schwarz Criterion being the minimum lag length and for the nature of the data.

\subsection{Results of the ARDL}

Table 6. Autoregressive Distributed Lag (ARDL) Model

\begin{tabular}{lllll}
\hline Variable & Coefficient & Std. Error & t-Statistic & Prob. \\
\hline $\mathrm{C}$ & $\mathrm{I} .330945$ & 3.437045 & 0.387235 & 0.6990 \\
\hline $\mathrm{NFA}(-\mathrm{I})$ & 0.638765 & 0.067898 & 9.407745 & 0.0000 \\
\hline
\end{tabular}




\begin{tabular}{lllll}
\hline EXPT & -0.275808 & 0.1 I I I02 & -2.482475 & 0.0325 \\
\hline NDC & -0.513939 & 0.165061 & -3.113628 & 0.0096 \\
\hline INC & 0.021686 & 0.063919 & 0.339270 & 0.7347 \\
\hline CM & -0.256245 & 0.070942 & -3.612036 & 0.0184 \\
\hline INTR & 0.145507 & 0.141922 & 1.025257 & 0.3064 \\
\hline INF & -0.039398 & 0.030838 & -1.277555 & 0.2028 \\
\hline EXCH & 0.086458 & 0.023829 & 3.622582 & 0.0162 \\
\hline MCIP & 0.061339 & 0.028177 & 2.057866 & 0.0213 \\
\hline \multicolumn{4}{r}{ R-Squared $=$} & 0.75 Adj. R-Squared = 0.74 F-Stat. = 64.888 Prob.(F-Stat.) $=0.000$ \\
& Source: Researcher's Computation 2019 &
\end{tabular}

The result of the autoregressive distributed lag (ARDL) was presented in Table 6. From this result, it was discovered that a direct linear relationship exist between net foreign asset and net foreign asset at lag one [NFA (-I)], income (INC), interest rate (INTR), exchange rate $(\mathrm{EXCH})$ and MCIP while, an inverse relationship was observed between the net foreign asset (NFA) and export (EXPT), net domestic credit (NDC), (CM), inflation rate (INF) of the countries during the period under study. The statistical significance of the estimated parameters of this model was examined using the standard error test and the probability value.

This result shows that one percent increase in net foreign asset at lag one, net foreign asset at lag two income, interest rate, exchange rate and MCIP will lead to 64, 17, 2, I5, 9 and 6 percent increases in net foreign asset while, one percent increase in value of export, net domestic credit, capital movement and inflation rate will cause the net foreign asset to reduce by 28 , 5I, 26 and 4 percent respectively in West Africa. Using standard error test, it was revealed that 0.319, 0.086, 0.138, 0.257, 0.128, 0.043, 0.03I which are greater than 0.068, 0.067, 0.III, 0.I65, 0.07I, 0.024 and 0.028 respectively for NFA(-I), NFA(-2), EXPT, NDC, CM, EXCH and MCIP. The same result is obtained using probability value as the prob. values of the estimated parameters 0.000, 0.01 I, 0.033, 0.009, 0.018, 0.016 and 0.02I $<0.05$ the probability of the error margin. Thus, it implies the statistical significant of the estimated parameters in determining the net foreign asset of the West African countries. The $R$ square value 0.75 revealed that 75 percent variation in the net foreign asset of the West Africa countries under consideration can be explained by the lags value of the net foreign asset, export, net domestic credit, income, capital movement, interest rate, inflation rate, exchange rate and MCIP. The probability of F-statistic $0.000<0.05$ shows the statistical significant of the autoregressive distributed lag model in balance of payments in the West African Monetary Zone countries using monetary approach.

\subsection{Hausman Result}

To determine the appropriate estimator between fixed effect and random effect the Hausman test was employed. Hausman Test compares fixed effect with random effect. If the Hausman test is insignificant (Prob $>\mathrm{Chi}^{2}$ greater than .05), then the fixed effects model will be used and vice versa. The result is therefore presented in table 4

Table 8. Hausman Result

\begin{tabular}{llll}
\hline Test Summary & Chi-Sq. Statistic & Chi-Sq. d.f. & Prob. \\
\hline Period random & 29.989784 & 8 & 0.0002 \\
\hline
\end{tabular}

Source: Researchers' computation (2019)

Table 8 presents the result of Hausman test which revealed that the chi-square value is 29.9898 and its P-values were 0.0002. The result showed that there is enough evidence to reject the null hypothesis of no substantial difference between fixed effect estimates and random effect estimates. The test revealed that fixed effect estimator is the most efficient and consistent during the study period.

\subsection{Panel Fixed Effect Result}

Table 9. Panel Fixed Effect

\begin{tabular}{lllll}
\hline Variable & Coefficient & Std. Error & t-Statistic & Prob. \\
\hline C & $-2.62 \mathrm{E}+\mathrm{II}$ & $\mathrm{I} .66 \mathrm{E}+\mathrm{II}$ & $-\mathrm{I} .580263$ & $0.1 \mathrm{I} 59$ \\
\hline NDC & $0.52207 \mathrm{I}$ & $0.024 \mathrm{I} 54$ & $2 \mathrm{I} .6 \mathrm{I} 458$ & 0.0000 \\
\hline MCIP & $5.44 \mathrm{E}+08$ & $2.07 \mathrm{E}+09$ & $0.26224 \mathrm{I}$ & 0.7935 \\
\hline INT & $2.70 \mathrm{E}+\mathrm{I0}$ & $\mathrm{I} .23 \mathrm{E}+\mathrm{I0}$ & 2.195278 & 0.0295 \\
\hline
\end{tabular}




\begin{tabular}{lllll}
\hline INF & $-1.61 \mathrm{E}+09$ & $2.95 \mathrm{E}+09$ & -0.544249 & 0.5870 \\
\hline INC & $2.62 \mathrm{E}+09$ & $5.12 \mathrm{E}+09$ & $0.5 \mathrm{I} 2333$ & $0.609 \mathrm{I}$ \\
\hline EXP0I & $0.377 \mathrm{I} 86$ & 0.135740 & 2.778729 & $0.006 \mathrm{I}$ \\
\hline $\mathrm{EXCH}$ & $-2.75 \mathrm{E}+08$ & $9557 \mathrm{I} 584$ & -2.882570 & 0.0045 \\
\hline $\mathrm{CM}$ & 0.009342 & 0.084638 & $0.1 \mathrm{I0371}$ & $0.9 \mathrm{I} 22$ \\
\hline \multicolumn{5}{c}{ Effects Specification } \\
\hline Period fixed (dummy variables) \\
\hline R-squared & 0.807372 & & \\
\hline Adjusted R-squared & 0.748795 & & \\
\hline F-statistic & $\mathrm{I} 3.78308$ & & \\
\hline Prob(F-statistic) & 0.000000 & & \\
\hline
\end{tabular}

Table 9 revealed the panel fixed effect which showed that the difference in beta coefficient of the variables have different contributions to Net Foreign Asset in developing countries. In this result, using the beta coefficient, NFA is negative at constant of -2.62 and its P-values were 0.I159. This means that when all variables are held constant, there will be a negative variation up to the tune of 2.62 units in NFA which implies that there is insignificant and negative effect of the independent variables to NFA at constant.

The result further showed that the regression coefficient of NDC was 0.522 and its P-value was 0.0000 . This implies that NDC has positive and significant effect on NFA in developing countries. The coefficient of MCIP was 5.44 and its Pvalues were 0.7935 and this implies that MCIP has a positive and insignificant effect on NFA. The regression coefficient of INT in NFA was 2.70 and its P-values were 0.02095.

The panel fixed effect equation showed that INT has a positive and significant effect on NFA. The regression coefficient of INF in NFA was-I.6I and its P-values were 0.5870. The result showed that INF has a negative and insignificant impact on NFA. The coefficient of INC was 2.62 and its P-values were 0.609I and this implies that INC has a positive and insignificant effect on NFA. The regression coefficient of EXPT in NFA was 0.377 and its P-values were 0.006I. This showed that EXPT has a positive and significant effect on NFA. The regression coefficient of EXCH in NFA was -2.75 and its Pvalues were 0.0045 . The result showed that EXCH has a negative and significant impact on NFA and the regression coefficient of CM in NFA was 0.009 and its P-values were 0.9I22. The result showed that CM has a positive and insignificant effect on NFA in the developing countries during the study period.

The result equally revealed that the coefficient of the regression which is the coefficient that depicts the estimated coefficient appears to be good while standard error and the values of t-statistic were equally presented in table 4.8. The results of other important statistical tools revealed that the coefficient of determination (R2) representing $80.7 \%$, the adjusted R-square $75.9 \%$, and the entire regression test is statistically significant including the F-test with P-values 0.0000 at $5 \%$ significance level.

\subsection{Summary and Implication of Findings}

The empirical proof gathered in this study has been to establish the fact that increased domestic credit, exports, and imports improves the BOP position contrary to the postulates of the monetary approach to balance of payment theory that increased money supply causes a distortion in the balance of payment position of a country. The reason could be the fact that the increased domestic credit expansion was able to boost the production, increased domestic output and more demand for inputs including imports. So, the economy was able to grow at a rate faster enough to absorb the rate of expansion in the net domestic credit which could have led to increased money supply and excess demand for goods and services.

Furthermore, the increase in exchange rate and inflation worsened the BOP position of these WAMZ countries. Normally, exchange rate ought to improve the BOP as it will reflect in currency appreciation, discouragement of imported goods and increased demand for domesticated goods.

\section{Conclusion and Recommendations}

This study assessed and investigated the impact of the monetary variables on the balance of payments of the West Africa Monetary Zone countries. The focus was to investigate the validity of the theoretical proposition of the monetary approach, rooted in Polak model, to the theory of $\mathrm{BOP}$ in a floating exchange rate system.

From the study, it has been confirmed to a large extent that the monetary approach is valid in explaining the BOP position of the WAMZ countries despite the fact that they are no more operating under a fixed exchange rate system as propounded by the theory. The objectives of the WAMI have not been achieved by the member countries, in terms of single digit inflation rate, positive real interest rate, real exchange rate stability and efficient level of foreign reserves.

The study thus recommended that: 
- The attention of the monetary authorities and the government should not only be on decreasing the money supply in the economy since an increase in net domestic credits has a positive impact on the net foreign assets provided it is channelled towards domestic production. This will eventually have a positive increase on exports and if supported by a policy of ban on importation, the BOP position will improve.

- The inclusion of exchange rate in the Polak model is also relevant since it has a direct effect on both imports and exports. Out of all the variables examined, exchange rate and net domestic credits have major impacts on the net foreign assets, therefore there is need for the monetary authorities and the governments to critically pay attention to the movements in exchange rate. Exchange rate adjustment could also be used as a policy tool because of its impact on imports, exports and even settlement of external debts

- There is also a need for stability in the economies and for investors not to be scared of investment, the economy need to be politically and socially stable. A suitable and positive environment gives birth to thriving investment which in turn improves the balance of payment.

\section{References}

Adamu, P. A. \& Itsede, O. C. (2010). Balance of Payment Adjustment: The West African Monetary Zone Experience. Journal of Monetary and Economic Integration, IO (2), IOO-I I6.

Adamu, P. A. (2004). The Dynamics of Balance of Payments Adjustment in Nigeria: An Error Correction approach. West African Financial and Economic Review, Econometrics, 3(2), 199-230.

Aghevli, B. B. (1977). The Monetary Approaches to the Balance of Payments Determination: An Empirical Test. International Monetary Fund Staff Papers, April(2), 275-290.

Ajayi, F. O. (20I4). Determinants of Balance of Payments in Nigeria: A Partial Adjustment Analysis. Journal of African Macroeconomic Review, 5(I), 304-3I I.

Arewa, A. \& Nwakamma, P. C. (2013). Money Supply and Velocity of Money in Nigeria: A Test of Polak Model. Journal of Management \& Sustainability, 3(4), I36-I50.

Akpasung, O. A. (2013). A Review of Empirical Literature on Balance of Payment as a Monetary Phenomenon. Journal of Emerging Trends in Economics and Management Sciences, 4(2), I24-I32.

Braima, S. J. \& Korsu, R. D (2013). Monetary Policy and the Balance of Payment: Econometric Evidence from Sierra Leonne. Journal of Sierra Leone Studies, 2(I). I- 5I.

Boateng, C. \& Ayentimi, D. (2013). An Empirical Analysis of Balance of Payment in Ghana, using the Monetary Approach. European Journal of Business \& Management, 5(8), I-20.

Dhliwayo, R. (1996). The Balance of Payments as a Monetary Phenomenon: An Econometric Study of Zimbabwe Experience. African Econometric Research Consortium (AERC), 46, I-36.

Duasa, J. (2005). The Malaysian Balance of Payment. Keynesian Approach versus Monetary Approach. International Islamic University, Malaysia Article, I-I5.

Fleemuys, F. N. (2005). The Balance of Payment as a Monetary Phenomenon: An Econometric Study of Namibia. DEA Research Discussion Paper 72, I-23.

Frenkel, J. \& Johnson, H.G. (1976). The Monetary Approach to the Balance of Payments: Essential Concepts and Historical Origin. In J Frenkel \& H. Johnson, (Eds). The Monetary Approach to Balance of Payments, Toronto, University of Toronto Press.

Ho, W. S. (2005). Application of Polak and Keynesian Model to Macao’s economy. Macao Monetary Authority Publications, 89-I08.

Ilesanmi, F. O. (2008). Monetary Approach to balance of payment. A test of Polak Model. Being a M. Sc. Thesis submitted to the Department of Banking and Finance, Ekiti State University.

Imoisi, A. I. (2012). Trends in Nigeria Balance Payment: An Empirical Analysis from I970 -20I0. European Journal of Business \& Management, 4(2I), 210 -2I7.

Imoughele, L. \& Ismaila, M. (2015). Monetary Policy \& Balance of Payment Stability in Nigeria. International Journal of Academic Research in Public Policy and Governance, 2(I), I-I5.

Iyoboyi, M. \& Muftau, O. (2014). Impact of Exchange Rate Depreciation on the BOP: Empirical Evidence from Nigeria. Cogent Economics and Finance, 2, I-23.

Johnson, H.G. (1972). The Monetary Approach to Balance of Payments Theory. Journal of Financial and Quantitative Analysis, 7(2), I666-I672.

Johnson, H. G. (1976). The Monetary Approach to the Balance of Payments Theory. In J. Frenkel and H.G. Johnson (Eds). The Monetary Approach to the Balance of Payments, Toronto, University of Toronto Press.

Johnson, H. G. (1977). Monetary Approach to Balance of Payment Theory: Explanation and Policy Implication. Jstor Economica, 44(175), 217-229. 
Khan, M. A. (2008). Long-run and Short-run Dynamics of Foreign Reserves and Domestic Credit in Pakistan. International Journal of Applied Econometrics and Quantitative Studies, 5(I).

Martin, R. (20I4). The Problem of BOP Imbalances. KWF Economic Research, I- 7.

Melink, H. A. (2003). Structural Adjustment Programmes on the African Continent: The Theoretical Foundation of IMF/ World Bank Reform Policies. African Study Centre Working Paper Series, (53), I-30.

Musa, M. (1976). Tariff and the Balance of Payments: A Monetary Approach. In Frenkel, J and Johnson, H. G. (eds). The Monetary Approach to the Balance of Payments, Toronto, University of Toronto Press.

Nyong, M. O. \& Obafemi, F. N. (1995). Exchange Rate Policy and Macroeconomic Adjustment in Nigeria: A Theoretical and Empirical Analysis with Policy Implication. Journal of Economics Studies I(I), Department of Economics, University of Calabar.

Obioma, G. O. (1996). Balance of Payments and Foreign Reserves Management in Nigeria: Empirical Evidence from the Monetary Approach. NCEMA Policy Analysis Series, 4(2), Technical Guide. Journal of International Economics, 7 , $251-268$.

Ogiogio, G. O. (1996). Exchange Rate Policy, Trade Policy Reform and the Balance of Payment. In Obadan, M. J. and Iyoha, M. A. (eds). Macroeconomic Policy Analysis: Tools, Techniques and applications to Nigeria. National Centre for Economic Management and Administration.

Ogiogio, T. M. (1996). Impact of External Sector Policies on Nigeria Economic Development. CBN Economic and Financial Review, 34(4).

Patrick, O. \& Sher, V. (2007). Current Account Deficits in Sub-Saharan Africa: Do they matter? United Nations Economic Commission for Africa Conference Proceedings, II(3), 24I-257.

Polak, J. J. (1957). Monetary Analysis, Income Formation and Payments Problems. International Monetary Fund Staff Papers, $6(\mathrm{I}), \mathrm{I}-50$.

Polak, J. J. (1997a). The International Monetary Fund Monetary Model. A Hardy Perrenial. Finance and Development, IMF.

Polak, J. J. (1997b). The IMF Monetary Model at Forty. International Monetary Fund Working Paper, WP/92/89.

Polak, J. J. (200I). Two Monetary Approach to the BOP: Keynesian and Johnsonian.

Shuaib, I. M., Augustine, O. E., \& Ogedengbe, F. (2015). Balance of Payments: Nigerian Experience. British Journal of Economics, Management and Trade, 7(4), 296 - 305.

Stephen, K. \& Njuyuna, N. (2000). Macro Models of the Keynesian Economy. A Review. Kenya Institute for Public Policy Research and Analysis Discussion Paper (2). 3 - 37.

Taiwo. (1992). An assessment of the Balance of Payment Crisis in Africa Using Bayesian Posterior Odds Ratio. The Nigerian Journal of Economic and Social Studies, 34(I), 3 I - 40.

Tijani, O. J. (20I4). Empirical Analysis of Balance of Payment Adjustment Mechanisms: Monetary Channel in Nigeria, I 970 2010. Mediterranean Journal of Social Sciences, 5(I4), 67- 76.

Umoru, D. \& Odjegba, O. (2013). Exchange Rate Misalignment and Balance of Payment Adjustment in Nigeria. European Scientific Journal, 9 (I3), $260-274$

Umer, M., Muhammad, S. D., Abro, A. A., Sheikh, Q. A. \& Ghazali, A. (2010). Balance of Payments as a Monetary Phenomenon: Econometric Evidence from Pakistan. International Research Journal of Finance and Economics.

WAMI. (2012). Inflation and Growth in the West African Monetary Zone: Evidence from a Threshold Analysis. West Africa Monetary Institute (WAMI) Occasional Paper Series I, 2- 38.

Wiolletta, N. (2013). Development of the Polak Model. Wroclaw Review of Law, Administration \& Economic Review, I8(I), 28-35.

Yotzov, V. (200I). Macroeconomic Models of the International Monetary Fund and the World Bank.(Analysis of Theoretical Approaches and Evaluation of their Effective Implementation in Bulgaria). National Bank of Bulgaria Discussion Paper, I4(2),6 -34.

\section{Copyrights}

Copyright for this article is retained by the author(s), with first publication rights granted to the journal. This is an open-access article distributed under the terms and conditions of the Creative Commons Attribution license (http://creativecommons.org/licenses/by/4.0/). 